\title{
Another Onset Mode for Rheumatoid Arthritis: Emergency Lab, Ultrasound or Both? Case Report and Literature Review
}

Alice Balaceanu ${ }^{1,2}$, Adriana Diaconu ${ }^{1,3}$, Adriana Stanica ${ }^{4}$, Camelia Diaconu ${ }^{1,5}$

\begin{abstract}
We report a case of a 41 years old woman, no medical or trauma history, who complains about intermittent leg pain for 2 months. Clinical exam showed important edema of both legs. Lab tests revealed positive inflammatory tests and coagulopathy. Bilateral giant hemorrhagic Baker's cyst was diagnosed by Doppler ultrasonography, CT and MRI. The positive diagnosis of rheumatoid arthritis with acute onset, causing severe inflammation of synovial knee joints, giant hemorrhagic cysts and disseminated intravascular coagulation was challenging.
\end{abstract}

Keywords: hemorrhagic Baker's cyst, rheumatoid arthritis, coagulopathy.

\section{Rezumat}

Este prezentat cazul unei paciente în vârstă de 41 de ani, fără antecedente patologice semnificative, fără traumatism recent, care solicită consult pentru fenomene algice gambiere cu debut de aproximativ 2 luni. Examenul clinic relevă edeme gambiere importante. Investigațiile de laborator au detectat prezența markerilor inflamatori specifici și coagulopatie. Ecografia Doppler, tomografia computerizată cu contrast și RMN-ul au pus diagnosticul de chist Baker hemoragic bilateral. Debutul acut al artritei reumatoide - asociind fenomene inflamatorii severe la nivelul articulației sinoviale a genunchiului, chist hemoragic gigant bilateral și teste sugestive de coagulopatie - pune în evidență încă o dată multiplele fațete clinice prin care se poate instala această afecțiune.

Cuvinte-cheie: chist Baker hemoragic, artrita reumatoidă, coagulopatie.

\section{INTRODUCTION}

Rheumatoid arthritis is a systemic autoimmune disease, with complex etiology and multiple genetic, immunologic, hormonal factors ${ }^{1}$. The onset could be insidious, like in the most patients or acute, with synovitis and extra-articular manifestations, encountered in $10 \%$ of patients ${ }^{1}$.

\section{MATERIALS AND METHODS}

We report a case of a 41 years old woman, non-smoker, without medical history, who complains about intermittent leg pain for 2 months, initially left calf, than bilateral, with edema in the both ankle and calf. The patient denied trauma. She is referred to emergency department for deep vein thrombosis suspicion. Cli-

\footnotetext{
1 "Carol Davila" University of Medicine and Pharmacy, Bucharest, Romania

${ }^{2}$ Department of Internal Medicine Emergency, "Sf. Ioan" Clinical Hospital, Bucharest, Romania

${ }^{3}$ Department of Pediatric-Hematology, Fundeni Clinical Hospital, Bucharest, Romania

${ }^{4}$ EUREKA CT/MRI Department, "Sf. Ioan" Emergency Clinical Hospital, Bucharest, Romania

${ }^{5}$ Department of Internal Medicine, Emergency Clinical Hospital, Bucharest, Romania
}

\section{Corresponding author.}

Alice Balaceanu, Department of Internal Medicine, "Sf. Ioan" Clinical Emergency Hospital, $13^{\text {th }}$ Vitan-Barzesti Avenue, 42122 , Bucharest, Romania.

E-mail: alicebalaceanu@yahoo.com 
nical exam showed important edema of both legs. Lab tests: microcytic hypochromic anemia $(\mathrm{Hb} 7.8 \mathrm{~g} / \mathrm{dL}$, HCT $26.6 \%$ ), mild leukocytosis with elevated neutrophils (WBC $12.0 \times 10 \% / \mathrm{L}$, Gran $76.9 \%$ ), secondary thrombocytosis (PLT $694 \times 10^{\%} / \mathrm{L}$ ), inflammatory biological syndrome (ESR $83 \mathrm{~mm} / \mathrm{h}$, Fibrinogen $684 \mathrm{~m} /$ dL, CRP $160.21 \mathrm{mg} / \mathrm{L})$, low serum iron levels $(24 \mu \mathrm{g} /$ $\mathrm{dL}$ ). Doppler ultrasound of lower limbs showed deep veins without thrombosis; complex fluid collection in the calves that begins above the popliteal space (Figure 1), more than $100 \mathrm{~mm}$ long diameter, inhomogeneous, hypoechoic.

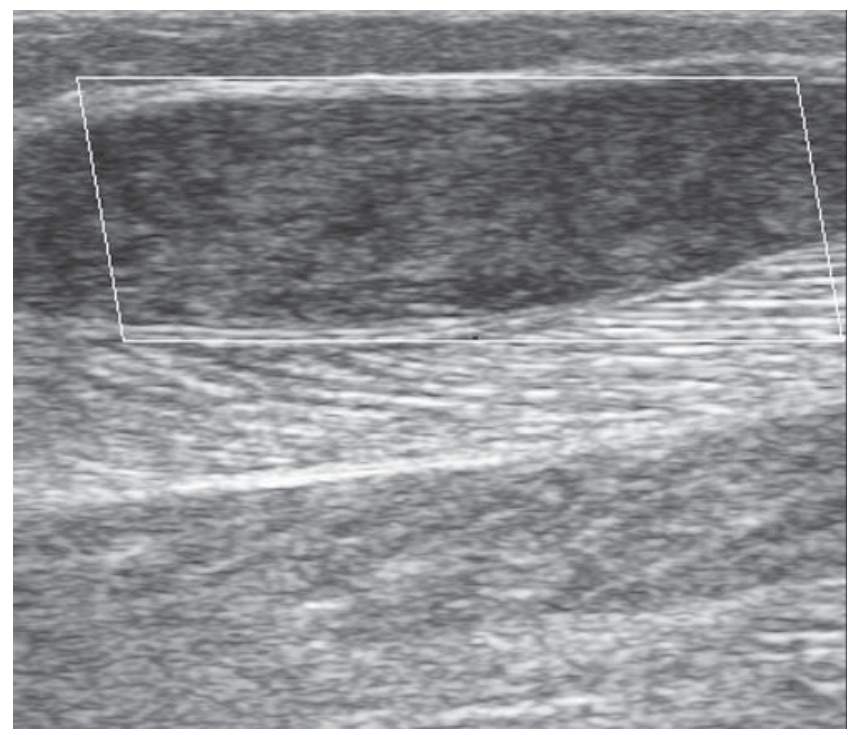

Figure 1. Doppler ultrasound of the calf: complex fluid collection, inhomogeneous, hypoechoic, no Doppler color signal, $25 \mathrm{~mm}$ short diameter, more than $100 \mathrm{~mm}$ long diameter, probably organized hematoma.

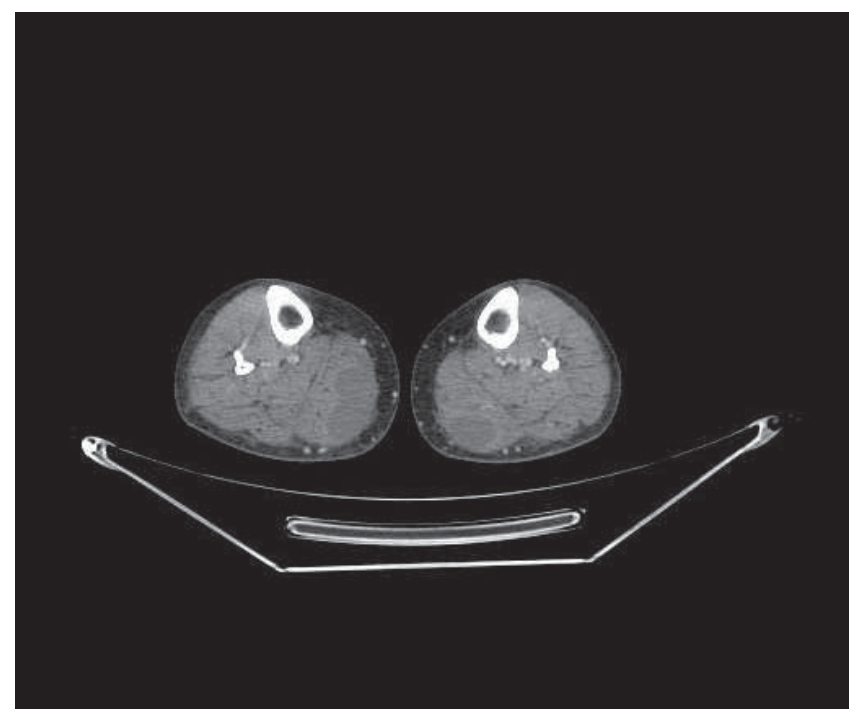

Figure 2. CT of the legs (axial vue): fluid encapsulated collections, well organized, with thin walls, heterogeneous serum and hemorrhagic densities, suggesting possible hematoma in bilateral gastrocnemius muscles.
CT of the legs: fluid encapsulated collections, well organized, with thin walls, heterogeneous serum and hemorrhagic densities, suggesting possible hematoma in bilateral gastrocnemius muscles (Figure 2). Abdominal ultrasonography, ECG, echocardiography were in normal limits. Specific blood tests showed chronic disseminated intravascular coagulation: PT activity 86\%, PT13.8 sec, INR 1.10, aPTT32.7 sec, factor VIII 254\%, VWF-Ag 284\%, factor X 34\%, factor XII $51 \%$, D-dimer $6730 \mu \mathrm{g} / \mathrm{L}$, positive FDP.

Clinical presentation of disseminated intravascular coagulation was chronic, bleeding type. Underlying conditions like sepsis or severe infection, trauma, malignancy, severe hepatic lesions, vascular lesions, toxic or immunologic reactions were evaluated.

Neoplastic markers (CA125, CA19-9, CEA, CA 15-3) were negative. Medullar aspirate showed reactive thrombocytosis. Cerebral, chest and abdominal CT, upper endoscopy and colonoscopy were normal.

Blood tests for $\mathrm{B}$ and $\mathrm{C}$ hepatitis and screening antiHIV antibodies were negative.

Autoimmune blood tests were performed: ANA, ANCA, anti ds-DNA antibodies, ASLO, complement, $\mathrm{C} 3$, C4, circulating immune complexes negative; rheumatoid factor $142 \mathrm{U} / \mathrm{mL}$, anti-CCP antibodies $65 \mathrm{U} /$ $\mathrm{mL}$ (normal limits under 7).

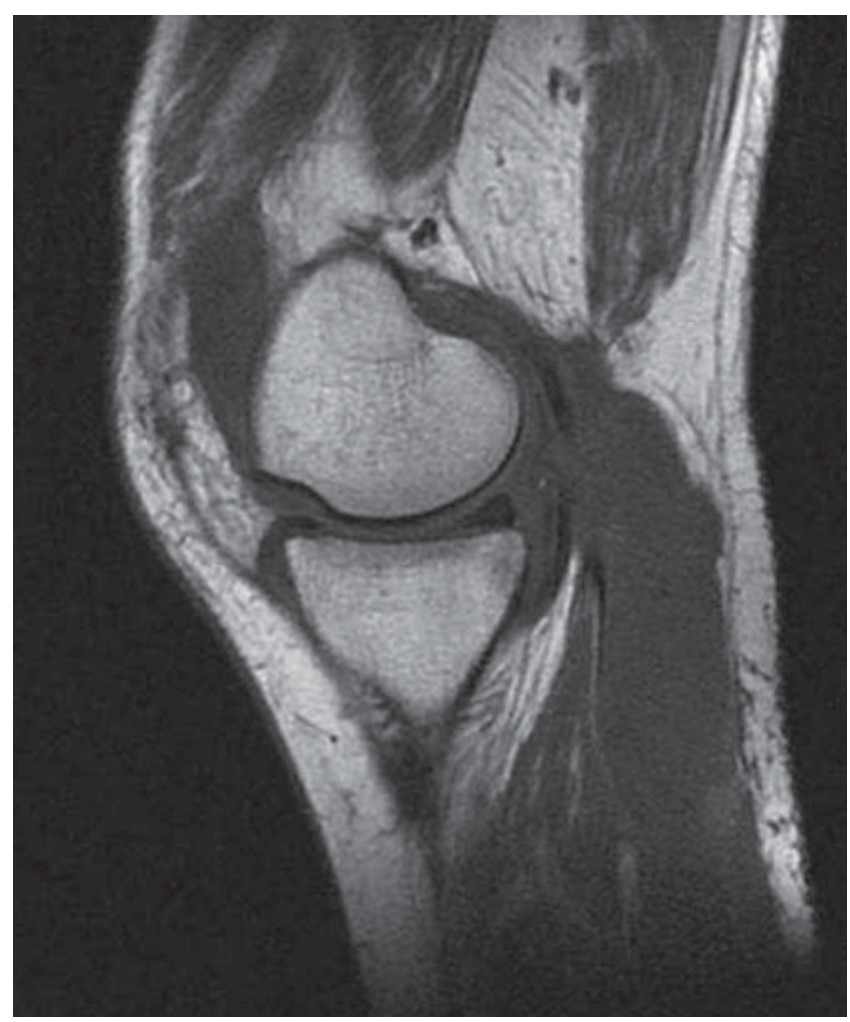

Figure 3. Contrast-enhanced MRI of the left calf (sagittal vue): Baker's cysts containing scratchy material, probably bleeding; moderate amount of fluid in the joint knees, changes of reactive synovitis. 


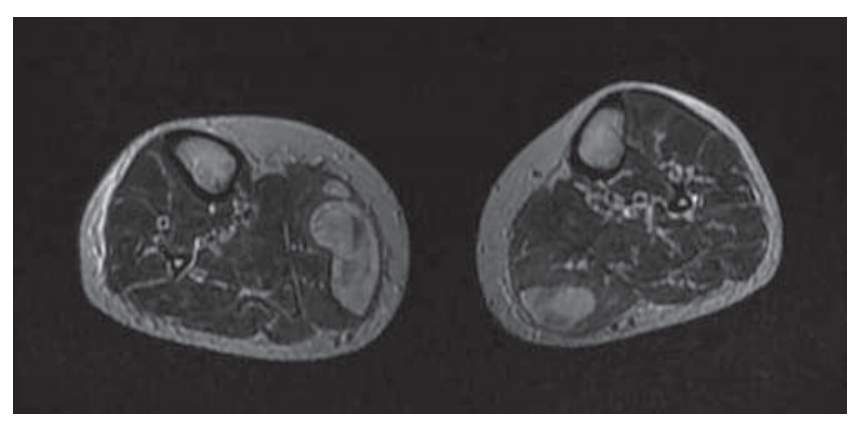

Figure 4. Contrast-enhanced MRI of the calves (axial vue):bilateral Baker's cysts containing scratchy material, probably bleeding.

MRI of the calves: bilateral Baker's cysts containing scratchy material, probably bleeding (Figure 3,4); moderate amount of fluid in the joint knees, more likely hemarthrosis; changes of reactive synovitis in both knees.

$\mathrm{X}$-ray films of the hands and legs: diffuse heterogeneous osteoporosis. Retinal exam was normal.

The diagnosis was set: Rheumatoid arthritis. Bilateral hemorrhagic Baker's cyst. Chronic disseminated intravascular coagulation. Secondary microcytic anemia. Reactive thrombocytosis. The score for rheumatoid arthritis diagnosis was 6/10, according American College of Rheumatology/European League Against Rheumatism (ACR/EULAR) 2010 criteria $^{2}$.

\section{RESULTS AND DISCUSSION}

Disseminated intravascular coagulation (DIC) has four variants: hyperfibrinolysis with bleeding, hypercoagulation, consumptive type with severe, fatal bleeding and non-symptomatic type ${ }^{3}$. The underlying etiological conditions make the differences between the clinical manifestations, but the types could change or shift ${ }^{3,4}$.

D-dimer and fibrinogen degradation products (FDP) elevations are specific parameters for bleeding type of $\mathrm{DIC}^{3}$, while high plasma levels of factor VIII and VWF, characteristic findings in DIC, cause platelet-vessel wall interaction, with organ failure ${ }^{5}$. The hypercoagulant status of inflammatory rheumatic di-

\section{References}

1. Rheumatoid arthritis clinical presentation. www.emedicine medscape.com/article/331715-clinical

2. Rheumatoid arthritis. http://www.dynamed.com/login.aspx?dir ect=true\&site=DynaMed\&id=115261.

3. Wada H, Matsumoto T, Yamashita Y. Diagnosis and treatment of disseminated intravascular coagulation (DIC) according to four DIC guidelines. Journal of Intensive Care 2014;2:1-15.

4. Diaconu C, Balaceanu A, Morosan E. Sepsis biomarkers: past, present and future. Farmacia 2015;63(6):811-815 sease implies endothelial activation, disturbance of plasmatic factors, dyscrasia, platelet activation, hyperviscosity ${ }^{5}$. In rheumatoid arthritis cases elevated CRP, ESR, fibrinogen, factor VIII and VWF increase plasma viscosity ${ }^{6}$. Endothelial cells play an important role in inflammatory rheumatic disease, DIC as presenting symptom at onset being also reported ${ }^{7}$. High values of CRP and ESR, anemia of chronic disease and thrombocytosis are characteristic features of rheumatoid vasculitis $^{8,9,10}$.

Activated platelets play also an important role in the inflammatory response of the synovial vessels: they promote vascular permeability, releasing inflammatory cytokines with an active role in leukocyte-mediated tissue inflammation ${ }^{11,12}$.

In an ultrasonographic study, the most frequently causes of Baker's cyst were osteoarthritis and rheumatoid arthritis ${ }^{13}$. Associated hematoma to Baker's cyst is an uncommon complication ${ }^{14}$. Ruptured Baker cyst could mimic deep vein thrombosis ${ }^{15,16}$.

In our case the presenting symptom was painful bilateral calf edema caused by hemorrhagic giant Baker's cysts. The diagnostic was made by Doppler ultrasonography and confirmed by contrast-enhanced CT and MRI. Acute onset of rheumatoid arthritis with severe inflammation of synovial knee joints and giant hemorrhagic cysts made the diagnosis very difficult, in the context of disseminated intravascular coagulation manifestations. As in other complex diseases, the diagnosis approach must be synergistic ${ }^{17}$. The evolution under appropriate treatment scheme and systematic surveillance was favorable.

\section{CONCLUSIONS}

Rheumatoid arthritis is a complex autoimmune condition, with a challenging diagnosis due to its multiple faces and its capricious coagulation and hematological implications.

Conflict of interests: none declared.

Financial support: none declared.

The patient has given the informed written consent.

5. Levi M, van der Poll T. Disseminated intravascular coagulation a review for the internist. Intern Emerg Med 2013;8:23-32.

6. Hoppe B, Dorner T. Coagulation and the fibrin network in rheumatic disease: a role beyond haemostasis. Nature Rheumatology 2012;8(12):738-746.

7. Sanada I, Kawano F, Tsukamoto A, et al. Disseminated intravascular coagulation in a case of adult onset Still's disease. Rinsho Ketsueki 1997;38(11):1194-8.

8. Turesson C, Matteson EL. Vasculitis in rheumatoid arthritis. Current Opinion in Rheumatology 2009;21(1):35-40. 
9. Watts RA. Rheumatoid vasculitis. Nat. Rev. Rheumatol. 2014;10: 261-262.

10. JCS Joint Working Group. Guideline for management of vasculitis syndrome. Circulation Journal 2011;75:474-503.

11. Boilard E, Blanco P, Nigrovic PA. Platelets: active players in the pathogenesis of arthritis and SLE. Nat. Rev. Rheumatol. 2012;8:534-542.

12. Elfarra M, Rădulescu D, Peride I, Niculae A, Ciocâlteu A, Checheriță IA, Lascăr I, Sinescu DR. Thromboangiitis obliterans - case report. Chirurgia (Bucur). 2015; 110(2):183-187.

13. Liao S-T, Chiou C-S, Chang C-C. Pathology associated to the Baker's cyst: a musculoskeletal ultrasound study. Clin Rheumatol 2010;29:1043-1047.
14. Yoo M-J, Yoo J-S, Jang H-S, Hwang C-H. Baker's cyst filled with hematoma at the lower calf. Knee Surg Relat Res 2014 26(4):253-256

15. Bakewell C, Dugowson C. Baker's cyst in a patient with rheumatoid arthritis. New England Journal of Medicine 2009;361 11:1098.

16. Dungan DH, Seeger LL, Grant EG. Case report 707: hemorrhagic Baker's cyst of the right calf. Skeletal Radiol. 1992;21(1):52-5.

17. Dragotoiu A, Checheriță Al, Ciocâlteu A, Rizeanu S. Synergistic approach to patient dialysate. J Med Life. 2015; 8 Spec Issue:66-68. 